\section{Ethephon and Silver Thiosulfate Affect Postharvest Characteristics of Rosa hybrida 'Victory Parade'}

\author{
Malgorzata Serek \\ Section for Horticulture, Department of Agricultural Sciences, The Royal \\ Veterinary and Agricultural University, Rolighedsvej 23, 1958 Frederiksberg \\ C., Denmark
}

\begin{abstract}
Additional index words. bud abscission, flower senescence
Abstract. The postharvest quality of miniature pot roses is limited by bud abscission and premature flower senescence. Rosa hybrida 'Victory Parade' plants were treated with ethephon to study their sensitivity to ethylene and with silver thiosulfate (STS) to investigate its inhibitory effects on ethylene action. Bud abscission and flower senescence were promoted by spraying plants with ethephon, and the longevity of individual flowers and whole plants was reduced. All STS concentrations (0.4, 0.8, 1.2, $1.6 \mathrm{mM})$ improved postharvest keeping quality. Bud abscission and flower senescence were decreased and the longevity of flowers and whole plants was improved by applying STS. Chemical name used: 2-chloroethylphosphonic acid (ethephon).
\end{abstract}

Abscission and senescence of flowers and flower buds reduce keeping quality of many flowering pot plants (Cameron and Reid, 1983; Fjeld, 1991; Serek, 1991). Ethylene has accelerated senescence in plant tissues (Reid, 1985). A common procedure to increase keeping quality of flowering pot plants that are sensitive to ethylene is to use an ethylene antagonist, e.g., silver ions (Agnew et al., 1985; Cameron and Reid, 1983; Fjeld, 1991). Silver ions inhibit ethylene action in plant tissues (Veen, 1983, 1986) and there by reduce senescence and abscission processes induced by ethylene.

The effects of ethylene and silver ions on miniature roses-one of the most importan pot plants in Denmark-have been studied little. In the present experiments, we sprayed potted 'Victory Parade' miniature rose plants with the ethylene-releasing compound ethephon toestablish whether the plants and flowers were sensitive to exogenous ethylene. Silver thiosulfate was used to try to improve postharvest plant characteristics.

'Victory Parade' rose cuttings were rooted in 0.55-liter, 10 -cm-diameter pots (four cuttings per pot) and grown under standard commercial conditions in the greenhouse. Greenhouse conditions were $22 / 21 \pm 2 \mathrm{C}$ day/night

Received for publication 23 Apr. 1992. Accented for publication 3 Nov. 1992. I thank Ante Skyt Andersen for fruitful discussions during this research, Michael S. Reid for critical review of the manuscript, F. Jackson Hills and Gail Nishimoto for advice on data analysis, and rose grower Ove Nielsen for kindly supplying the plants. The project was supported by grant no. 13-4.549 from the Danish Agricultural and Veterinary Research Council and supplementary grants from Foundation of Hofmansgave, Foundation of Ib Henriksen, and Carlsberg Foundation. The cost of publishing this paper was defrayed in part by the payment of page charges. Under postal regulations, this paper therefore must be hereby marked advertisement solely to indicate this fact. treatments, the plants were evaluated (day -3) and then transferred to simulated shipping conditions without irrigation $[8 \pm 2 \mathrm{C}, 90 \% \pm$ $5 \%$ relative humidity $(\mathrm{RH})]$ in darkness. After shipment, the plants were reevaluated and moved into a controlled interior-environment room at $20 \pm 2 \mathrm{C}$ and $60 \% \pm 5 \% \mathrm{RH}$. Plants were exposed to light from fluorescent tubes $12 \mathrm{~h} \cdot \mathrm{day}^{-1}$ at $15 \mu \mathrm{mol} \cdot \mathrm{m}-2 \cdot \mathrm{s}^{-1} \mathrm{PPF}$ and irrigated from above with tap water as needed. The experiment was completed 35 days after the end of simulated shipping in darkness, which lasted 3 days.

The following data were collected:

1) All flowers and flower buds were counted atharvest (day-3), at day 0 (i.e., before and after simulated shipping in darkness), and thereafter every 5 days (a total of eight times).

2) The longevity of individual flowers that had opened before simulated shipping was ascertained by counting the number of days from anthesis to petal drying or abscission.

3) The longevity of plants was considered to be the number of days from harvest (day -3) to when only three flowers remained on the plant.

Statistical procedures were performed using SAS's personal computer software package (SAS, 1985). The variance of the experimental data was tested, and orthogonal comparisons were used to examine differences between means.

Ethephon. Treatment with ethephon caused a linear decline in plant and individual flower longevity and total number of flowers per plant (Table 1). Plants treated with arelatively low concentration of ethephon $(50 \mathrm{ppm}) \mathrm{de}-$ creased in all areas only slightly from those of the control (Tables 1 and 2). Bud abscission was promoted strongly by spraying with 500 ppm ethephon; all flowers and buds had fallen by day 10 (Table 2). The ethephon spray also reduced the number of flowers that opened during storage and in the interior-environment room (data not shown).

The effects of ethylene on flowering pot plants have been studied by many (Cameron and Reid, 1983; Hoyer 1984, 1985; Woltering, 1987). Ethylene induces flower and flower bud abscission in Begonia elatior Sirene, and flower, flower bud, and leaf abscission in Hibiscus rosa-sinensis (Heyer, 1984, 1985). Woltering (1987) investigated the sensivity of

Table 2. Number of flowers and flower buds of Rosa hybrida 'Victory Parade' plants before and after transport and during storage in an interior-environment room after preharvest ethephon treatments.

\begin{tabular}{|c|c|c|c|c|c|}
\hline \multirow{2}{*}{$\begin{array}{l}\text { Ethephon } \\
\text { concn (ppm) }\end{array}$} & \multicolumn{5}{|c|}{ Days in interior-environment room (no.) } \\
\hline & -3 & 5 & 10 & 15 & 20 \\
\hline \multicolumn{6}{|c|}{ Flowers (no.) } \\
\hline 0 & 7 & 13 & 13 & 4 & 1 \\
\hline 50 & 6 & 12 & 11 & 4 & 0 \\
\hline 500 & 7 & 4 & 0 & 0 & 0 \\
\hline Significance & NS & $\mathrm{L}^{* * *}$ & $\mathrm{~L}^{* * *}$ & $\mathrm{~L}^{*}$ & NS \\
\hline \multicolumn{6}{|c|}{ Flower buds (no.) } \\
\hline 0 & 30 & 29 & 15 & 8 & 2 \\
\hline 50 & 32 & 26 & 14 & 6 & 1 \\
\hline 500 & 30 & 19 & 0 & 0 & 0 \\
\hline Significance & NS & $\mathrm{L}^{*}$ & $\mathrm{~L}^{* * *}$ & $\mathrm{~L}^{* * *}$ & NS \\
\hline
\end{tabular}

$\mathrm{NS}, * * * *$ Nonsignificant or significant at $P=0.05$ or 0.001 , respectively; $\mathrm{L}=$ linear. 
ornamental pot plants to exogenous ethylene by exposing them to ethylene; in general, flowering pot plants were sensitive to ethylene. These results support the present experiment. 'Victory Parade' rose plants were sensitive to ethylene; consequently, the ethylene antagonist STS may prevent the destructive action of ethylene and prolong the longevity of

Table 3. Longevity of individual flowers opened before shipping and of plants (defined as the number days until only three flowers remained), and total number of flowers per Rosa hybrida 'Victory Parade' plant developed during the life of the plant in relation to various preharvest STS treatments.

\begin{tabular}{lccc}
\hline \hline $\begin{array}{l}\text { Treatment } \\
\text { (mM STS) }\end{array}$ & \multicolumn{2}{c}{ Longevity (days) } & $\begin{array}{c}\text { Total flower } \\
\text { count }\end{array}$ \\
\cline { 2 - 3 } & Plant & Flower & 18.8 \\
\hline 0 & 15.7 & 20.8 \\
0.4 & 31.6 & 21.5 & 36.0 \\
0.8 & 31.9 & 20.3 & 35.5 \\
1.2 & 31.8 & 20.9 & 34.1 \\
1.6 & 31.3 & 17.7 & 33.7 \\
Significance & $\mathrm{Q}^{* * *}$ & $\mathrm{Q}^{* * *}$ & $\mathrm{Q}^{*}$ \\
\hline
\end{tabular}

****Significant at $\mathrm{P}=0.05$ or 0.001 , respectively; $\mathrm{Q}=$ quadratic. plants and flowers not treated with ethylene.

STS. Treatment with STS caused a quadratic trend in plant and flower longevity and total flower count (Table 3). All STS concentrations markedly increased the longevity of rose plants $(66 \%$ to $70 \%)$ and of individual flowers (13\% to $37 \%$ ) compared to the control plants (no STS). The number of flowers developed during the life of the plant was $62 \%$ to $73 \%$ higher after all STS treatments than for nontreated plants (Fig. 1). Total flower count and individual flower longevity decreased at doses higher than $0.4 \mathrm{~mm}$. This result suggests that the optimal STS concentration may be lower than $0.4 \mathrm{~mm}$.

The numbers of flowers and buds were indistinguishable during simulated transport and during transfer to the interior-environment room, regardless of treatment (Table 4; day -3). From days 10 to 25 after shipment, STS treatments showed a quadratic trend in the number of flowers; the same trend was observed in the number of buds from day 20 (linear trend from day 15). Also, all STS concentrations reduced bud abscission and

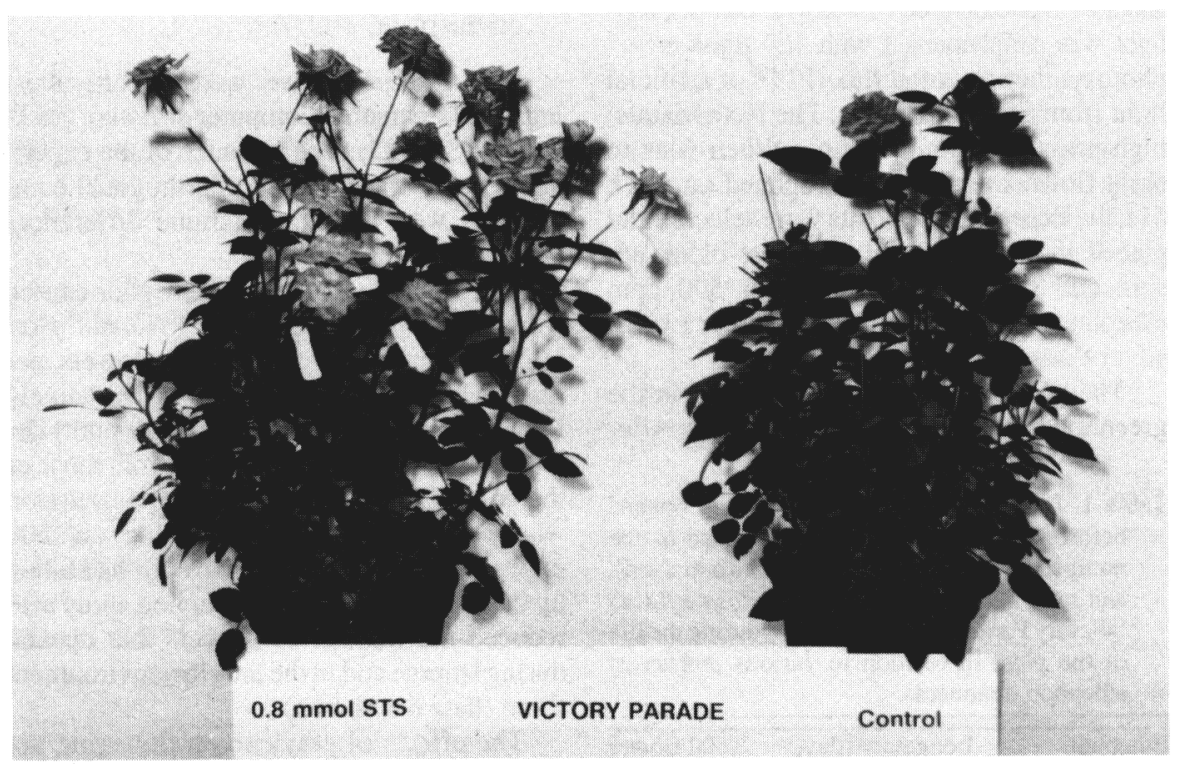

Fig. 1. Rosa hybrida 'Victory Parade' plants treated with $0.8 \mathrm{~mm}$ silver thiosulfate (left) and control plants (right). The photograph was taken 18 days after simulated shipping.

Table 4. Number of flowers and flower buds before and after simulated transport of Rose hybrida 'Victory Parade' plants and during storage in an interior-environment room after preharvest STS treatments.

\begin{tabular}{|c|c|c|c|c|c|}
\hline \multirow{2}{*}{$\begin{array}{l}\text { STS } \\
\text { concn (mM) }\end{array}$} & \multicolumn{5}{|c|}{ Days in interior-environment room (no.) } \\
\hline & -3 & 10 & 15 & 20 & 25 \\
\hline \multicolumn{6}{|c|}{ Flowers (no.) } \\
\hline 0 & 7 & 13 & 4 & 0 & 0 \\
\hline 0.4 & 6 & 24 & 22 & 8 & 4 \\
\hline 0.8 & 7 & 21 & 21 & 9 & 6 \\
\hline 1.2 & 5 & 20 & 22 & 11 & 7 \\
\hline 1.6 & 7 & 17 & 14 & 10 & 2 \\
\hline \multicolumn{5}{|c|}{ Flower buds (no.) } & $\mathrm{Q}^{* *}$ \\
\hline 0 & 30 & 15 & 7 & 1 & 0 \\
\hline 0.4 & 32 & 20 & 15 & 10 & 7 \\
\hline 0.8 & 34 & 17 & 14 & 10 & 6 \\
\hline 1.2 & 30 & 20 & 15 & 11 & 5 \\
\hline 1.6 & 31 & 18 & 15 & 8 & 5 \\
\hline Significance & NS & NS & $\mathrm{L}^{*}$ & $\mathrm{Q}^{*}$ & $Q^{*}$ \\
\hline
\end{tabular}

NS,*******Nonsignificant or significant at $P=0.05,0.01$, or 0.001 , respectively; $\mathrm{L}=$ linear, $\mathrm{Q}=$ quadratic.

increased flower opening during the postharvest period from day 15 and day 10 (data not shown). No foliage nor flower damage was observed in STS-sprayed rose plants.

These results demonstrate that silver treatments significantly improve plant and flower longevity, increase the number of flowers per plant, and prevent bud abscission in miniature roses. These effects are similar to previous results obtained in other flowering pot plants, such as Begonia $\times$ cheimantha Everett (Fjeld, 1991), Calceolaria herbeohybrida Voss, Pelargonium hortonum Bailey, Bougainvillea glabra Chois. (Cameron and Reid, 1983), and Streptocarpus (Agnew et al., 1985).

Several unpublished experiments have investigated the direct sensitivity of miniature roses to ethylene and the possibility of using silver ions to prolong plant keeping quality. The postharvest keeping quality of Rosa hybrida 'Lady Meillandina', 'Sweet Minimo', 'Femini Rosamini', 'Red Minimo', and 'Spicy Minijet' increased strongly after STS treatments (J. Hansson, J. Nowak, M. Serek, unpublished). However, certain cultivars, e.g., 'Spicy Minijet' (J. Hansson, unpublished) and 'Starlight Parade' (M.S., unpublished), did not benefit clearly from STS treatments following exposure to ethylene. The divergent results among cultivars are genetic in origin.

'Victory Parade' was sensitive to ethephon, and treatments with silver ions effectively improved this cultivar's postharvest keeping quality. All STS concentrations had positive effects, but, for environmental and economical reasons, $0.4 \mathrm{~mm}$ STS is the recommended concentration, although a lower concentration may be optimal.

\section{Literature Cited}

Agnew, N.H., M.L. Albrecht, and R.K. Kimmins. 1985. Reducing corolla abscission of Streptocarpus xhybridus under simulated shipping conditions with silver thiosulfate. HortScience 20:118-119.

Cameron, AC. and M.S. Reid. 1983. Use of silver thiosulfate to prevent flower abscission from potted plants. Scientia Hort. 19:373-378.

Fjeld, T. 1991. Effects of silver thiosulfate, ethephon, temperature, and irradiance level on keeping quality of christmas begonia (Begonia xcheimantha Everet). Gartenbauwissenschaft 56(2):66-70.

Hoyer, L. 1984. Bud, flower and leaf drop in Hibiscus rosa-sinensis caused by ethylene and darkness. Tidsskrift Planteav188:489-501.

Høyer, L. 1985. Bud and flower drop in Begonia elatior 'Sirene' caused by ethylene and darkness. Acta Hort. 167:387-391.

Reid, M.S. 1985. Ethylene and abscission. HortScience 20:45-50.

SAS Institute. 1985. SAS/STAT guide for personal computers. version 6. SAS Institute, Cary, N.C.

Serek, M. Effects of pre-harvest supplementary irradiance on decorative value and ethylene evolution of Campanula carpatica 'Karl Foerster' flowers. Scientia Hort. 48:341-347.

Veen, H. 1983. Silver thiosulfate: An experimental tool in plant science. Scientia Hort. 181:155160.

Veen, H. 1986. A theoretical model for anti-ethylene effects of silver thiosulfate and 2,5-norbornadiene. Acta Hort. 181:129-134.

Woltering, E.J. 1987. Effects of ethylene on ornamental pot plants: Aclassification. Scientia Hort. 31:283-294. 